\title{
Hvorfor skal Danmark stå skoleret for FN?
}

Af Jonas Christoffersen

Hvorfor skal Danmark egentlig stå skoleret for FN? Hvorfor skal FN bestemme over Danmark? Hvorfor fylder menneskerettighederne så meget? Hvorfor kan vores politikere ikke bare selv bestemme, hvad der skal ske i Danmark? Den slags spørgsmål høres ofte i den offentlige debat. Normalt er det på blogs og i mundtlige samtaler, at modstanden mod FN og mod de internationale menneskerettigheder fylder mest. Men kritikken lyder også fra politiske og juridiske kredse.

Da Højesteret i 2011 fejrede sit 350 år jubilæum holdt præsidenten, Børge Dahl, en tale, hvor han blandt andet udtrykte skepsis over for den internationale udvikling af menneskerettighederne:

"Højesteret har naturligvis en dansk tilgang til den opgave, som internationaliseringen har ført med sig. For os er også menneskerettigheder menneskeværk. Hvert land har sit svar på, hvor balancepunktet mellem jura og politik ligger. Det danske balancepunkt er demokratisk funderet, og det er vigtigt, at udviklingen in- ternationalt ikke bliver så dynamisk, at man ikke kan følge med nationalt."

Den danske grundlov er baseret på det grundsynspunkt, at politikerne og ikke dommerne bestemmer, hvad der skal gælde i kongerigets retssystem. Grundloven fylder ikke særlig meget, og det er en demokratisk styrke.

Også fra politisk hold skydes mod menneskerettighederne. Da Venstre i august 2014 lancerede en ny udlændingepolitik sværgede Venstre først respekt for de internationale konventioner. "Danmark er underlagt en række internationale forpligtelser, der har betydning for udlændingeområdet. En ny udlændingepolitik skal naturligvis respektere disse forpligtelser." Men som noget nyt tilføjede Venstre:

"Konventioner er ikke uforanderlige, men udtryk for politiske forhandlinger og kompromiser. Derfor kan vi søge at ændre dem, og vi bør ikke frasige os muligheden for at opsige en konvention i de helt særlige tilfælde, hvor en konvention fører til åbenlyst urimelige resultater."

Der er i Danmark og internationalt en livlig debat om menneskerettighederne.

Jonas Christoffersen er dr. jur. og siden 2009 direktør for Institut for Menneskerettigheder. Han har været ansat som forsker på Københavns Universitet (2000-2008], konstitueret landsdommer ved Østre Landsret [2006-2007) og dommerfuldmægtig i Højesteret [1998-1999). Jonas Christoffersen har skrevet disputats om Den Europæiske Menneskerettighedsdomstol. 


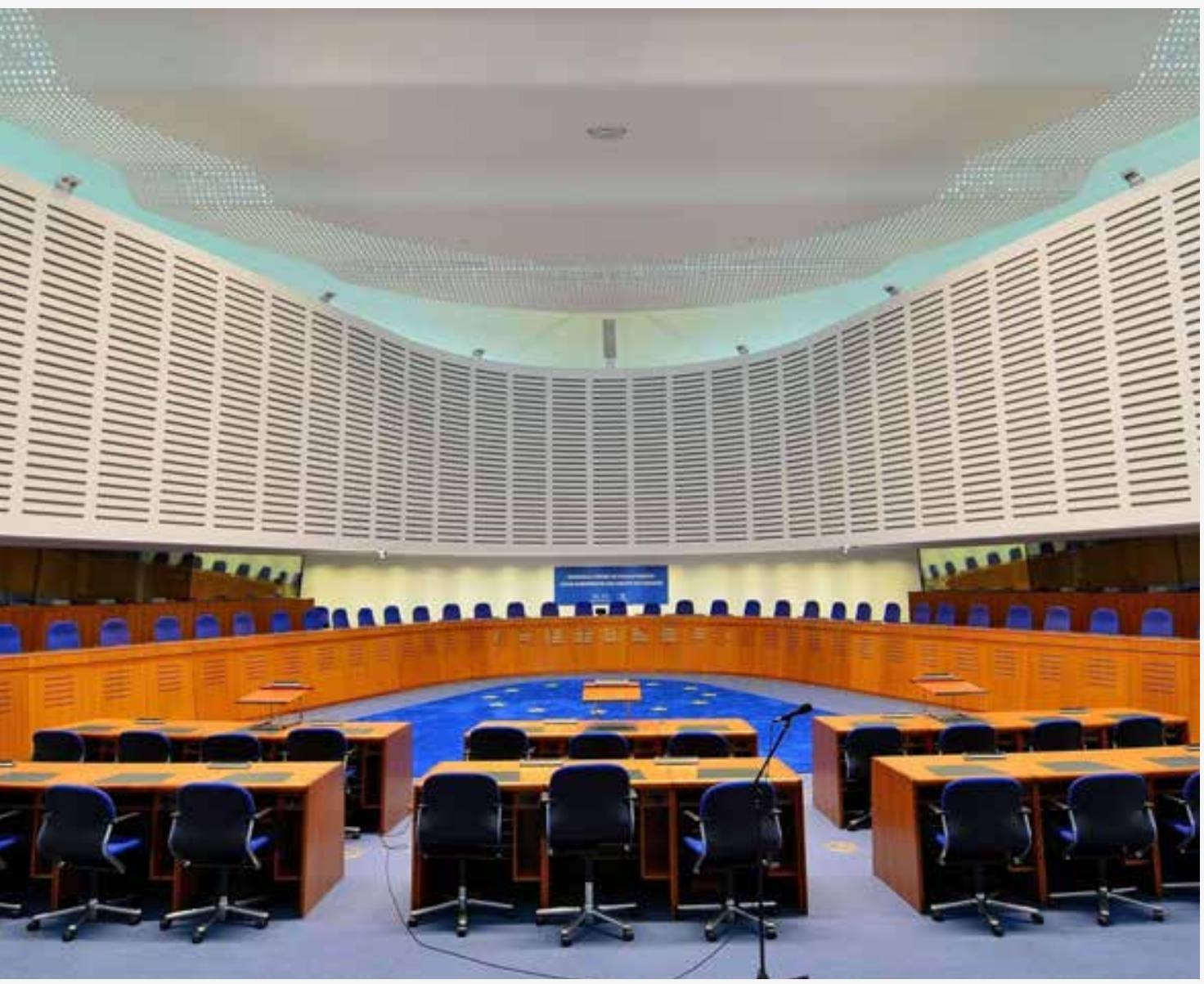

FOTO: Foto: Adrian Grycuk, via Wikimedia Commons.

Retssalen, Den Europæiske Menneskeretsdomstol i Strassbourg. 
Men hvordan er det kommet dertil, og hvad gør vi ved det?

\section{Efter Anden Verdenskrig}

Efter Anden Verdenskrig greb verdens lande dybt i posen for at finde nye midler til at forhindre en gentagelse af krigen. FN's charter blev allerede den 26. juni 1945 vedtaget med fokus på "at styrke og fremme respekten for menneskerettigheder og for fundamentale frihedsrettigheder for alle uden forskel med hensyn til race, køn, sprog eller religion," som det blandt andet hedder i charterets artikel 1. Beskyttelsen af menneskerettighederne var fra starten en kerneopgave for FN. Danmark førte - ligesom de øvrige nordiske lande - en udenrigspolitik med fokus på globalt samarbejde. Norske Trygve Lie var således FN's første generalsekretær fra 1946 til 1952, og han blev efterfulgt af svenske Dag Hammerskjöld fra 1953 til 1961.

I 1948 vedtog FN's Generalforsamling Verdenserklæringen om menneskerettigheder. Verdenserklæringen er ikke vedtaget af FN's medlemsstater, der i stedet har vedtaget en lang række internationale konventioner til beskyttelse af menneskers rettigheder. De vigtigste FN-konventioner omhandler: Flygtninges rettigheder (1952), Statsløses rettigheder (1961), Civile og politiske rettigheder (1966), Økonomiske, sociale og kulturelle rettigheder (1966), Kvinders rettigheder (1979) Torturforbud (1985), Børns rettigheder (1989), og Handicappedes rettigheder (2006).

Også i Europa var der fokus på menneskerettighederne. Den Europæiske Menneskerettighedskonvention blev vedtaget i 1950, og i 1958 blev der etableret en Domstol, der kunne tage stilling til klager over de europæiske staters overtrædelse af menneskerettighederne. Skandinaverne spillede en central rolle i det europæiske menneskerettighedsarbejde. Den svenske diplomat Sture Petren indtog en væsentlig rolle ved etableringen af Menneskerettighedskonventionen og var præsident for Menneskerettighedskommissionen fra 1962-1966.

Den danske professor Max Sørensen efterfulgte ham og spillede en nøglerolle i den sag, som Danmark havde været med til at anlægge mod Grækenland for at påtale militærjuntaens grove overtrædelser af menneskerettighederne. Dengang var talemåden en anden, så de græske generaler kaldte sagen en konspiration udtænkt af bøsser og kommunister, men de skandinaviske lande stod fast og brugte menneskerettighedssystemet til at protestere mod militærjuntaens udemokratiske magtmisbrug. Ude i den store verden dominerede kampen mod apartheid i Sydafrika, mod militærjuntaerne i Sydamerika og mod kommunismen i Østeuropa. Det var nok sådan, vi i de skandinaviske lande forestillede os, at menneskerettighederne skulle bruges: langt fra landets grænser og på problemer langt fra vores standarder.

\section{Udviklingen tager fart}

Men i midten af 1970'erne tog udviklingen fart. Alle Europarådets medlemmer havde efterhånden tiltrådt Den Europæiske Menneskerettighedskonvention, og alle lande - bortset fra Frankrig - havde accepteret, at borgerne kunne klage til Menneskerettighedsdomstolen. EF-domstolen begyndte i samme periode at udvikle menneskerettigheder i EF, hvor de i øvrigt kaldes grundrettigheder.

Politisk set fik menneskerettighederne ny betydning, da både vest- og østeuropæiske lande underskrev den såkald- 
"Konventioner er ikke uforanderlige, men udtryk for politiske forhandlinger og kompromiser. Derfor kan vi søge at ændre dem, og vi bør ikke frasige os muligheden for at opsige en konvention i de helt særlige tilfælde, hvor en konvention fører til åbenlyst urimelige resultater." [Citat fra Venstres lancering af en ny udlændingepolitik i august 2014]

te Helsinki-aftale, hvorefter landene i øst og vest skulle respektere menneskerettighederne. Amnesty International fik i 1977 Nobels Fredspris for sit arbejde med menneskerettighederne. I dette politiske klima begyndte Menneskerettighedsdomstolen i Strasbourg at udvikle menneskerettighederne til at få en mere konkret betydning for den indenrigspolitiske situation i Europa. Domstolen fastslog, at menneskerettighederne udvikler sig i overensstemmelse med det omkringliggende samfund, og at de skal yde en praktisk og effektiv beskyttelse af borgerne. Det foregik i god overensstemmelse med nordiske værdier. Den danske højesteretsdommer og forhenværende justitsminister, Helga Pedersen, spillede således en central rolle i 1970'ernes udvikling, og norske Rolv Ryssdal var Domstolens vicepræsident fra 1981-1984 og dens præsident fra 1985 til 1998.

Danmark blev op igennem 1960'erne, 70'erne og 80'erne indbragt for Domstolen et par gange, men hver gang blev Danmark frikendt. I 35 år fra 1953 til 1988 havde Danmark kort sagt ikke indenrigspolitiske problemer med menneskerettighederne. Kun da Storbritannien i 1981 blev dømt for at opretholde eksklusivaftaler på arbejdsmarkedet, fik Danmark problemer. Men det var på et meget snævert område, og problemet var ikke større, end at det kunne løses uden større sværdslag. Det kunne ved selvsyn konstateres, at der var harmoni mellem danske og internationale standarder. Forestillingen var vel stadigvæk, at de internationale menneskerettigheder lå langt fra danske standarder
- eller rettere sagt: Danmark var højt hævet over de internationale menneskerettigheder. At Danmark kunne få problemer med de internationale menneskerettigheder, stod indtil slutningen af 1980'erne for det fleste som en meget mærkelig påstand.

\section{Danmark på anklagebænken}

I Danmark kom menneskerettighederne først for alvor på den indenrigspolitiske dagsorden i 1989. Tre begivenheder var helt afgørende for udviklingen. Danmark blev den 24. maj 1989 for første gang dømt af Domstolen i Strasbourg. Det var en sag, hvor en dansk dommer havde været inhabil, idet han efter at have varetægtsfængslet en person mere end 30 gange også skulle dømme i straffesagen. Få dage forinden havde Folketinget den 19. maj 1989 ved en folketingsbeslutning opfordret regeringen til at nedsætte et udvalg for at undersøge fordele og ulemper ved gøre Den Europæiske Menneskerettighedskonvention til en del af dansk lovgivning.

Udvalget anbefalede i en betænkning i 1991, at Den Europæiske Menneskerettighedskonvention blev gjort til en del af dansk lovgivning. Det skete i 1992 med virkning fra 1. januar 1993. Der blev dermed sat en tyk politisk streg under ønsket om, at Danmark holdt sig på den rigtige side af menneskerettighederne som de fortolkes og anvendes af Menneskerettighedsdomstolen. Og endelig for det tredje udtalte Højesteret den 29. august 1989 i en sag om tvangsfjernelse af et barn, at bistandsloven må forstås "i overensstemmelse med de afgørelser, som Den Europæiske Menneskerettighedsdomstol har 
truffet vedrørende tilsvarende spørgsmål." Menneskerettighedsdomstolens praksis kom dermed helt ind i juraens daglige maskinrum i de danske domstoles retslokaler, ligesom truslen om at klage til Menneskerettighedsdomstolen blev en del af den politiske og juridisk hverdag. 25 år efter går der ikke en dag, uden at aviser og andre medier henviser til menneskerettighederne på alle mulige forskellige samfundsområder.

\section{Den internationale overvågning}

Menneskerettighederne har udviklet sig fra tandløse papirtigre til effektive trusler mod politikeres krænkelse først og fremmest på grund af de internationale overvågningsmekanismer. Ud over Den Europæiske Menneskerettighedsdomstol og Den Europæiske Unions Domstol er der i FN oprettet klagekomiteer i tilknytning til de store konventioner. Klagekomiteerne består af normalt 17 eksperter fra forskellige dele af verden. Klagekomiteerne behandler klagesager fra enkeltpersoner, men det modtager også rapporter fra medlemslandendes regeringer om situationen i de enkelte lande, hvorefter komiteerne kan komme med anbefalinger til, hvordan situationen kan forbedres. Danmark er inden for det seneste år blev vurderet af FN's Handicapkomite, FN's Kvindekomite og FN's Komite for Økonomiske, Sociale og Kulturelle Rettigheder, ligesom Danmark i november blev vurderet af FN's Torturkomite.

Ud over ekspertkomiteerne behandler FN's Menneskerettighedsråd løbende spørgsmål om alle medlemsstaternes overholdelse af menneskerettighederne. Det sker både ved tematiske og landespecifikke drøftelse, men det sker ikke mindst i den såkaldte Universelle Periodiske Bedømmelse (på engelsk Universal Periodic Re- view eller UPR). UPR blev opfundet i 2005 for at styrke Menneskerettighedsrådets fokus på de faktiske forhold $\mathrm{i}$ alle lande. Da menneskerettighedsrådet består af staterne, er der tale om en politisk og diplomatisk vurdering. Det kan derfor ikke undre, at processen er politiseret og derfor ikke altid afspejler de internationale standarder, som ekspertkomiteerne arbejder ud fra. Men det opsigtsvækkende ved processen er, at alle lande skal rapportere til Menneskerettighedsrådet om alle menneskerettigheder - uanset om medlemsstaterne har tiltrådt de konkrete konventioner.

Det betyder, at UPR bliver et udstillingsvindue, hvor landene ikke kan gemme sig bag sædvanlige henvisninger til ikke-indblanding i interne forhold eller til respekten for visse rettigheder frem for andre. Danmark skal derfor - i lighed med alle andre lande i FN - bedømmes af FN's menneskerettighedsråd, og det sker næste gang i januar 2016.

\section{Hvad skal man mene om det?}

Det er først som sidst et politisk spørgsmål, hvordan man forholder sig til udviklingen, der er politisk bestemt. Rent politisk er sagen klar: der er intet udemokratisk ved, at lovgivningsmagten sætter grænser for lovgivningsmagten. Det er lovgivningsmagten (regeringen og Folketinget), der har fastholdt en 65 årig tradition for at bevare Danmark inden for det internationale samarbejde om menneskerettigheder. Folketinget skal efter grundloven give sit samtykke, hver gang regeringen vil tilslutte sig en international menneskerettighedskonvention. Danske politikere har løbende fornyet Menneskerettighedsdomstolens kompetence i perioden fra 1953 til 1998, ligesom Danmark tilsluttede sig, at Domstolen blev permanent fra 1998. Danmark besluttede i 1992 
at gøre Menneskerettighedskonventionen til en del af dansk lovgivning. Og Folketinget har aldrig lovgivet i bevidst strid med den internationale menneskeret. Det skorter således ikke på politiske beslutninger, der forankrer Danmark i det internationale samarbejde om menneskerettighederne.

Alt dette kan imidlertid ikke sløre, at menneskerettighederne har ændret den måde, det danske demokrati fungerer på, og at politikere undertiden kan ønske menneskerettighederne hen hvor peberet gror - også når de gør deres pligt og stemmer ja til endnu et lovforslag, der hviler på respekt for menneskerettighederne. Det er navnlig inden for udlændingepolitikken, at modstanden mod den internationale menneskeret er størst, men der er også en bredere kritik af, at danske politikere har afgivet for megen magt til det internationale samarbejde, og at Danmark for tit skal stå skoleret på for mange områder.

\section{En international boomerang}

Uanset den indenrigspolitiske ambivalens fortsætter Danmark med i udenrigspolitikken at holde fanen højt på menneskerettighedsområdet. Det er ét af flere områder, hvor Danmark forsøger at markere sig, fx. med Mogens Lykketoft som formand for FN's Generalforsamling. Danmark indtager også formandskabet for Europarådet fra november 2017 til maj 2018, og Danmark er kandidat til FN's Menneskerettighedsråd i 2018.

Danmark er en småstat, der forsøger at tiltuske sig blød magt ved at vifte med den internationale og menneskeretlige fane. Men vi var ikke opmærksomme på, at menneskeretten kunne ramme os i nakken som en boomerang, vi selv havde været med til at kaste. I SF-S-R regeringsgrundlaget fra 2011 hed det blandt andet: "Diplomati og dialog skal være omdrejningspunktet i dansk udenrigspolitik. Danmark skal yde støtte til fremme af menneskerettighederne, styrke indsatsten for at fremme god regeringsførelse og samfund baseret på retsstatsprincipper, samt støtte udvikling af demokratiske institutioner. Indsatsen for menneskerettighederne starter dog med, at vi sikrer os, at de altid respekteres hos os selv."

Den sidste sætning tror jeg ikke, vi kommer til at se i fremtidige regeringsgrundlag. Vi vil trods hellere fokusere på, hvordan andre skal respektere menneskerettighederne. For her i landet går det jo godt. Heldigvis. 